\title{
VARIATION OF FEEDING HABITS OF LUTJANUS PERU (ACTINOPTERYGII: PERCIFORMES: LUTJANIDAE) CAUGHT IN TWO REGIONS OF THE GULF OF CALIFORNIA, MEXICO
}

\author{
Xchel G. MORENO-SANCHEZ ${ }^{1}$, Leonardo A. ABITIA-CARDENAS ${ }^{1}$, \\ Gisela TRUJILLO-RETANA ${ }^{1}$, Andrés F. NAVIA³, Jorge S. RAMÍREZ-PÉREZ2*, \\ and Bernardo SHIRASAGO-GERMAN ${ }^{1}$
}

${ }^{1}$ Instituto Politécnico Nacional, Centro Interdisciplinario de Ciencias Marinas, Av. IPN s/n, La Paz, Baja California Sur, México

${ }^{2}$ Universidad Autónoma de Sinaloa, Unidad Regional Sur, Edificio de Vicerrectoría, Av. Ejército Mexicano s/n, Ciudad Universitaria Mazatlán, Sinaloa, México

${ }^{3}$ Fundación colombiana para la investigación y conservación de tiburones y rayas, Cali, Colombia

\begin{abstract}
Moreno-Sánchez X.G., Abitia-Cardenas L.A., Trujillo-Retana G., Navia A.F., Ramírez-Pérez J.S., Shirasago-German B. 2016. Variation of feeding habits of Lutjanus peru (Actinopterygii: Perciformes: Lutjanidae) caught in two regions of the Gulf of California, Mexico. Acta Ichthyol. Piscat. 46 (2): 97-108.
\end{abstract}

Background. The Pacific red snapper, Lutjanus peru (Nichols et Murphy, 1922), is one of the most exploited species by artisanal fisheries in Mexico, where it is valued due to its high catch rates and economic value. This study investigated the feeding habits of L. peru in two ecosystems of the southern Gulf of California with contrasting physical and oceanographic conditions. Feeding habits were compared by sex (male or female), size (juvenile or adult), and season (cold or warm), in order to determine whether this species plays the same trophic role in the two ecosystems.

Materials and methods. Samples were obtained from the northern Sinaloa coast (SIN region) and south-eastern Baja California Sur coast (BCS region). Percentages by number, weight, and frequency of each food category were determined, and the index of relative importance (\%IRI) was calculated to define the main food categories. Diet breadth and diet similarity between sexes, sizes and among seasons were also calculated.

Results. A total of 182 stomachs from the SIN region were analysed and 32 prey items from 15 families, 18 genera, and 25 species were identified. According to the index of relative importance (IRI), the most important prey items were the shrimp, Penaeus californiensis (73\%); the ostracods, Myodocopida gen spp. (10\%); and the squid, Loligo spp. (5\%). A total of 233 stomachs from BCS were analysed and 31 prey items from 17 families, 19 genera, and 26 species were identified. The most important prey items according to the IRI were the red pelagic crab, Pleuroncodes planipes (42\%); the ostracods, Myodocopida gen spp. (28\%); and the shrimp, Penaeus californiensis $(20 \%)$. Significant differences were identified in the trophic spectra by region, size and season. There were no significant differences by sex.

Conclusion. Lutjanus peru displayed a specialist trophic behaviour, with differential utilization of the trophic niche and adequate food resource distribution.

Keywords: Artisanal fisheries, trophic spectrum, specialist predator, Penaeus californiensis, Pleuroncodes planipes

\section{INTRODUCTION}

The feeding habits of predatory fishes are influenced by several ecological, biological, and environmental factors (Muto et al. 2001, Rinewalt et al. 2007, Wetherbee et al. 2012). Size and sex are biological factors frequently associated with diet variation in fishes (Griffiths et al. 2009, Wetherbee et al. 2012). In general, changes in diet have been associated with differing dental structures in

* Correspondence: Dr. Jorge S. Ramírez-Pérez, Universidad Autónoma de Sinaloa, Unidad Regional Sur, Edificio de Vicerrectoría, Av. Ejército Mexicano s/n, Ciudad Universitaria Mazatlán, Sinaloa, México, C.P.8200, phone/fax: (+52) 669 9828656, e-mail: (JSRP) jramirezp@uas.edu.mx, (XGMS) xchel.moreno@gmail.com, (LAAC) laabitia@gmail.com, (GTR) gisela27trujillo@gmail.com, (AFN) anavia@squalus.org, (BSG) bshirasago@ipn.mx. 
males and females (Hernández and Motta 1997, Saucedo Lozano et al. 2006), as well as with changes in prey type or in the proportion of items consumed by juveniles and adults (Rojas et al. 2004, Yan et al. 2012, Moreno-Sánchez et al. 2015).

There is evidence, that variation in the diet of bony fishes is also affected by environmental variables (Santamaría et al. 2003, Guevara et al. 2007), by species distribution, and by prey availability (Blaber and Bulman 1987, Rojas and Chiappa 2002). Different authors have also stated that these variations presumably reflect the migratory character of predators or of their prey (Blaber and Bulman 1987, Rinewalt et al. 2007, HernándezAguilar et al. 2013).

Snappers (Lutjanus spp.) are known to be generalist carnivores, with a diet based on benthic invertebrates such as shrimp, crab, and polychaetes (Allen 1985, Parrish 1987, Guevara et al. 2007, Vázquez et al. 2008). They present ontogenetic changes in the diet, with higher consumption of fish at larger sizes (Saucedo-Lozano et al. 1999, Santamaría et al. 2003).

Studies coincide in that the trophic spectrum of Lutjanus peru (Nichols et Murphy, 1922) varies with sex and ontogeny. Juveniles consume crustaceans, whereas adults specialize on eating fish (e.g., sardines and anchovies) and crustaceans (e.g., stomatopods) (Santamaría et al. 2003, Saucedo Lozano et al. 2006). It has also been suggested that snappers could play an important role in the structure and function of marine trophic webs, acting as a link between the highest and lowest levels of the trophic web (Arreguín and Manickchand 1998), or even dampening the dispersion of secondary trophic effects derived from anthropogenic impacts (Navia et al. 2012).

As the previous studies on the diet of Lutjanus peru did not analyse spatial variation, there is no background information on diet changes in this species in closely situated ecosystems with contrasting physical and oceanographic conditions. This is the case of the southern Gulf of California region, where the continental coast is characterized by sandy and muddy substrates with important pluvial contributions and numerous coastal lagoons, whereas the peninsular coast has a reduced platform with a mostly rocky substrate and large reef patches (Obeso et al. 2004, Rodríguez et al. 2005).

The presently reported study was carried out to test the hypothesis that the feeding habits of Lutjanus peru are influenced by physical and oceanographic conditions. For that, we compared $L$. peru diet in two ecosystems within the Gulf of California with distinct conditions.

\section{MATERIALS AND METHODS}

Biological sampling. The study period comprised 13 months from February 2011 to March 2012. Samples were collected monthly in two regions of the southern Gulf of California. Region SIN, corresponded to the zone of Topolobampo Sinaloa $\left(25^{\circ} 19^{\prime} 34.17^{\prime \prime} \mathrm{N}, 109^{\circ} 32^{\prime} 40.07^{\prime \prime} \mathrm{W}\right)$, and the second region $\mathrm{BCS}$ corresponded to the eastern coast of Baja California Sur in La Paz Bay $\left(25^{\circ} 01^{\prime} 26.88^{\prime \prime} \mathrm{N}, 110^{\circ} 35^{\prime} 00.57^{\prime \prime} \mathrm{W}\right)$ (Fig. 1). Both areas are characterized by two well defined seasons: a cold season that occurs from January to March, and a warm season that occurs from July to September, with their respective transitional periods (Guevara-Guillén et al. 2015, Lavín and Marinone 2003). Fish were caught from artisanal fishing boats using 60 to $90 \mathrm{~m}$ long weighted handlines, using number 6 and 7 J-type hooks. All fishing was carried out over rocky, soft, and mixed substrates.

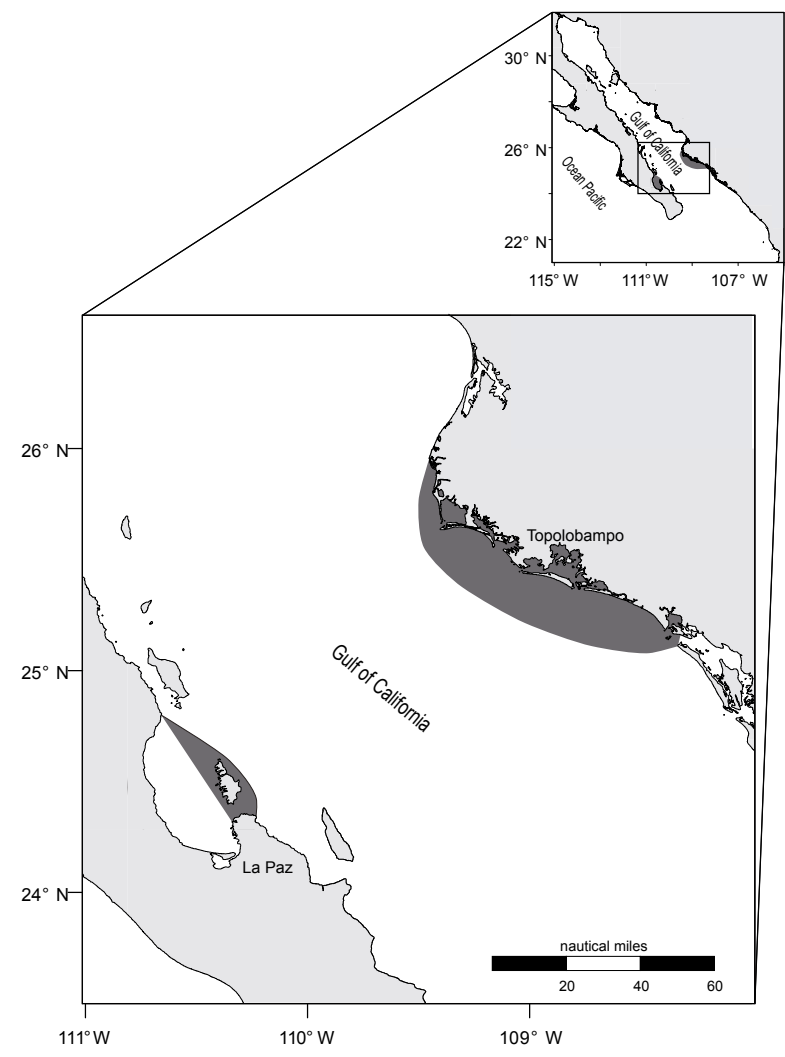

Fig. 1. The shaded area shows the Pacific red snapper, Lutjanus peru, sampling locations; In the Sinaloa (SIN) region fish were landed in Topolobampo, whereas in the Baja California Sur (BCS) region they were landed in La Paz Harbour

Each captured specimen was measured and total length (TL, $\pm 0.5 \mathrm{~cm}$ precision), and total weight ( $\mathrm{TW}, \pm 1 \mathrm{~g}$ precision) were recorded. Sex was determined by direct gonadal observation, and the stomachs were extracted and frozen for later processing.

Stomach contents were identified to the lowest possible taxonomic level. The data were grouped by sampling region (SIN and or BCS), by sex (the degree of vascularization, turgency, and texture, and in some cases the type of oocyte visible to the naked eye were taken into account to identify female gonads, and the testicular turgency and flowing semen were taken into account to identify male gonads (Ferreri et al. 2009), by developmental stage (fish were considered juveniles if they measured less than $22 \mathrm{~cm}$ TL for both females and males, Cruz et al. 1996), and by season (warm or cold). The sea surface temperature was obtained from MODIS-AQUA satellite images with a $1.1 \mathrm{~km}$ resolution at the nadir in the Hierarchical Data Format. Data extraction 
was performed using WIM (Windows Image Manager) software. The months with positive anomalies were assigned to the warm season, while months with negative anomalies were assigned to the cold season. These anomalies were obtained with respect to the annual mean value calculated between February 2011 and March 2012 for both areas; this annual mean value was $24^{\circ} \mathrm{C}$ (Fig. 2).

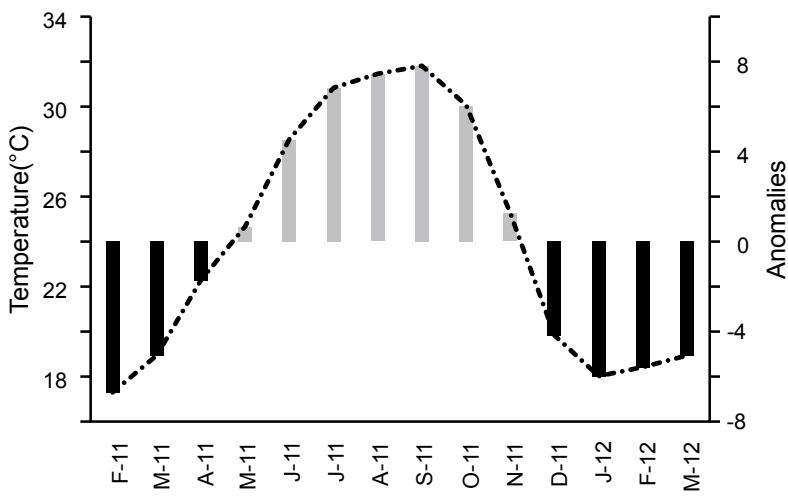

Fig. 2. Sea surface temperature by month (dashed lines) in the southern Gulf of California during 2011 and 2012; Black bars denote cold season values and grey bars denote warm season values; The primary $y$-axis shows the temperature in degrees Celsius and the secondary $y$-axis shows anomalies with respect to the overall mean values

Feeding habits. A species accumulation curve-EstimateS (Colwell 2009) based on the Shannon-Wiener $\left(H^{\prime}\right)$ index value for each stomach was calculated to determine the representativity of the number of analysed stomachs. The coefficient of variation $(\mathrm{CV})$ was calculated to obtain a quantitative estimate of the number of stomachs that was adequate and representative of the general diet, as well as of the diet by category: location (SIN-BCS), sex factor (female-male), size (juveniles-adults), and season (warmcold). If the $\mathrm{CV}$ was less than or equal to $5 \%(0.05)$, the examined number of stomachs was considered an adequate representation of the diet (Jiménez-Valverde and Hortal 2003, Hernández-Aguilar et al. 2013).

The quantitative analysis of stomach contents was performed using the numeric $(\% N)$, gravimetric $(\% W)$, and frequency of occurrence $(\% F)$ indices (Hyslop 1980), and the index of relative importance following Pinkas et al. (1971):

$$
\mathrm{IRI}=\% N+\% W \times \% F
$$

These quantitative analyses were used to characterize and compare the diet by region (SIN or BCS), sex (male or female), size (juvenile or adult), and season (cold or warm).

The diet width was estimated using the ShannonWiener index:

$$
H^{\prime}=-\sum_{i=1}^{n}\left(\frac{n_{1}}{N}\right) \log 2\left(\frac{n_{1}}{N}\right)
$$

where $n$ is the number of individuals of species $i, N$ is the total number of individuals of all prey species (Magurran 1988). In order to interpret the feeding strategy of Lutjanus peru and establish the feeding patterns of individuals or populations we used the graphical Costello (1990) method modified by Amundsen et al. (1996).

Data analysis. To evaluate the possible effects of sex, size, and season on the diet of Lutjanus peru in SIN and BCS we used a non-metric multidimensional scaling analysis (NMDS). An analysis of similarities (one-way ANOSIM, with 999 permutations) was performed to test for differences in diet according to sex, size, and season (Dale et al. 2011). The resulting $R$ statistic $(-1<R<1)$ describes the similarity between groups defined according to the above factors. Values close to zero indicate no difference, and values close to 1 or -1 indicate a significant separation between groups. $P$ values were considered significant when $P<0.05$. Similarity percentages (SIMPER) were used to determine which dietary categories contributed significantly to the dietary dissimilarity between the analysed variables (Clarke 1993).

Trends in the diet according to variations found by sex, size, and season within and between SIN and BCS were evaluated using a simple correspondence analysis (Graham and Vrijenhoek 1988). To confirm the relation among species diet (with dietary categories as dependent variables), catch sites, seasons, and sex (as independent variables), a multivariate analysis of variance (MANOVA) was applied, using $\% N$.

Data preparation for multivariate analysis was carried out according to White et al. (2004) and Marshall et al. (2008). Namely, dietary data for a single individual contained large numbers of zero values, giving rise to instabilities in the calculation of similarities at an individual level, which greatly reduces the effectiveness of multivariate analyses of dietary data. This problem was efficiently minimized by averaging the dietary data $(\% N)$ for random groups of individuals to produce a new series of replicates for a given factor (e.g., season, size class, or sex). Before multivariate analyses, the $\% N$ data for dietary categories of each subset (i.e., replicate) were square-root transformed and used to construct a BrayCurtis similarity matrix for non-metric multidimensional scaling (NMDS) ordination and a one-way ANOSIM test (Clarke and Gorley 2006).

Taxonomic names of the invertebrates were verified based on the World Register of Marine Species: WoRMS (WoRMS Editorial Board 2016), while names of fishes followed FishBase (Froese and Pauly 2016).

\section{RESULTS}

Diet. A total of 497 fish were caught, ranging in size from 12 to $67 \mathrm{~cm} \mathrm{TL}$, and ranging in weight from 40 to $5945 \mathrm{~g}$. A total of 415 fish had stomachs containing food (83.5\%) and 82 had empty stomachs (16.5\%). The trophic diversity curve analysis showed that the sample size was adequate to describe the diet of this species for all analysed variables and for each region studied (Table 1, Fig. 3). 

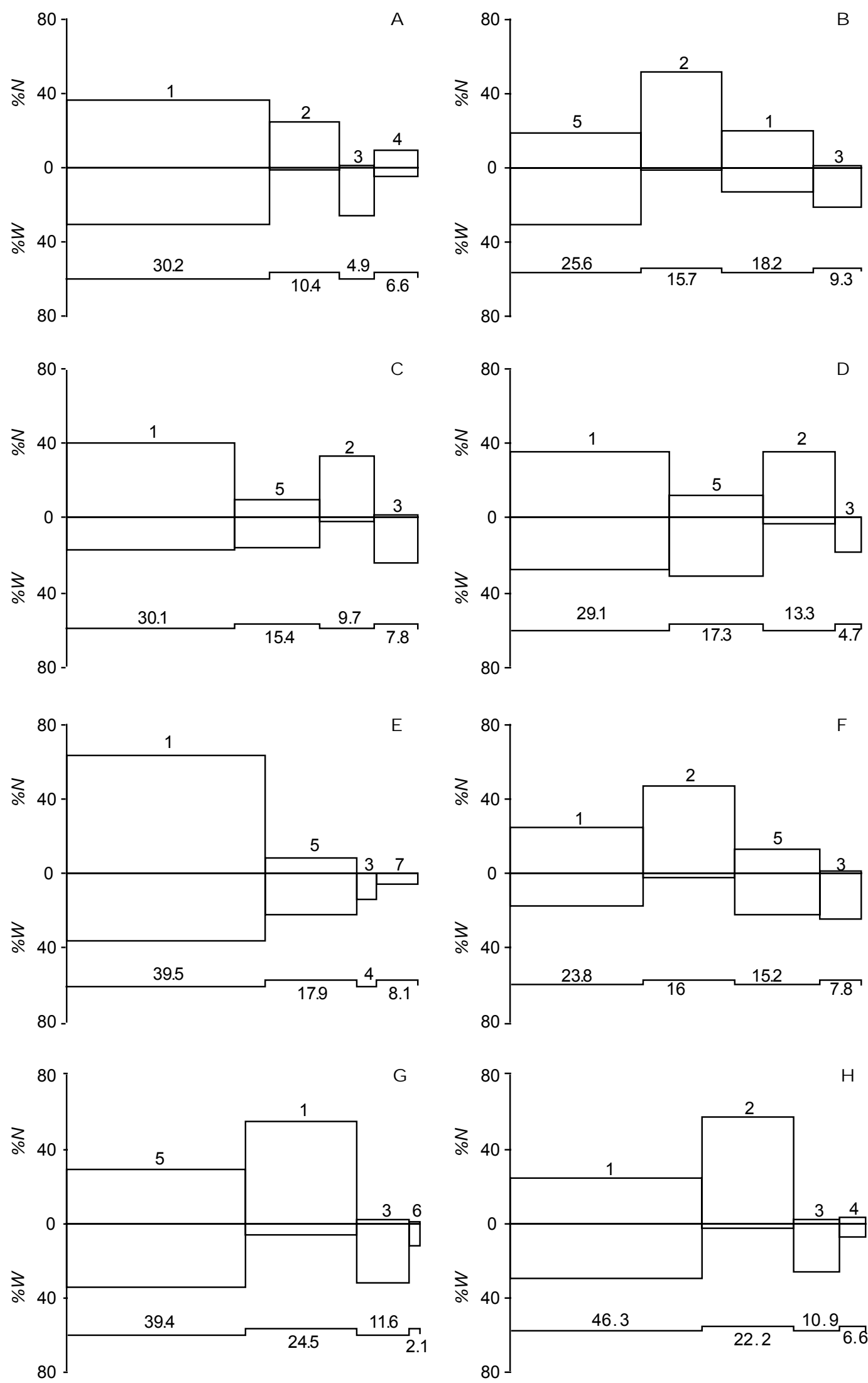

$\% F$

Fig. 3. Variation of prey species consumed by Lutjanus peru determined with the Index of Relative Importance (IRI); Sinaloa (A), Baja California Sur (B), females $(\mathbf{C})$, males $(\mathbf{D})$, juveniles $(\mathbf{E})$, adults $(\mathbf{F})$, cold season $(\mathbf{G})$, warm season (H); Abbreviations: $\% N=$ percentage by number, $\% W=$ percentage by weight, $\% F=$ percentage frequency of occurrence 
Diet region. Twenty-five prey species were identified in 182 stomachs at SIN. A total of 1622 organisms were counted, weighing $741.15 \mathrm{~g}$, with crustaceans comprising by number and biomass was the shrimp, Penaeus californiensis $(30 \% \mathrm{~N}$ and $30 \% \mathrm{~W})$, followed by ostracods, Myodocopida gen spp. $(25 \% \mathrm{~N})$, and the pelagic red crab, Pleuroncodes planipes $(5 \% \mathrm{~W})$. According to the \%IRI, the most important prey item was Penaeus californiensis (73\%), followed by Myodocopida gen spp. (10\%), and the squid, Loligo spp. (5\%) (Table 2, Fig. 3a).

In BCS, 26 prey species were identified in 233 stomachs. A total of 2962 organisms were counted, weighing 1849.4 $\mathrm{g}$, with crustaceans comprising $96 \% \mathrm{~N}$ and $54 \% \mathrm{~W}$, followed by molluscs with $2 \% N$ and $41 \% W$. The most abundant prey items were Myodocopida gen spp. $(46 \% \mathrm{~N})$, whereas the species with greatest biomass were Pleuroncodes planipes $(31 \% W)$ and Loligo spp. $(22 \% W)$. The most important prey according to the $\%$ IRI were $P$. planipes ( $42 \%$ ), followed by Myodocopida gen spp. (28\%) and Penaeus californiensis (20\%) (Table 2, Fig. 3b).

The Pacific red snapper can be categorized as a specialist carnivorous predator. The Shannon-Wiener index values by region (SIN and BCS; $0.1 \pm 0.3$ and $0.2 \pm$ 0.4 bits per ind.), sex (females and males; $0.1 \pm 0.4$ and 0.1 \pm 0.3 bits per ind.), maturity state (juveniles and adults; $0.15 \pm 0.31$ and $0.25 \pm 0.43$ bits per ind.), and season (cold and warm; $0.10 \pm 0.25$ and $0.18 \pm 0.31$ bits per ind.) were low. The Costello graph showed that the most frequent and abundant prey species were Penaeus californiensis and Pleuroncodes planipes, which confirmed the Pacific red snapper's specialist trophic behaviour (Fig. 4).

The sex factor. A total of 29 prey species were identified in 231 female stomachs. The \%IRI showed that Penaeus californiensis (63\%) was the most important species in the trophic spectrum, followed by Pleuroncodes planipes (15\%), and Myodocopida gen spp. (12\%) (Fig. 3c). A total of 26 prey species were identified in 184 male stomachs. The \%IRI showed that the most important species were Penaeus californiensis (56.1\%), Pleuroncodes planipes (22.7\%), and Myodocopida gen spp. (15.9\%) (Fig. $3 d)$. Results of the NMDS and ANOSIM did not show a significant effect of sex on the diet of the Pacific red snapper in either location studied (Fig. 5, Table 3).

Diet item size. A total of 22 prey species were identified in 164 stomachs from juvenile fish. According to the \%IRI the most important species were Penaeus californiensis (84\%), followed by Pleuroncodes planipes (12\%), and Loligo spp. (1\%) (Fig. 3e). A total of 32 prey species were identified in 251 adult stomachs. According to the \%IRI the most important species were Penaeus californiensis (39\%), Myodocopida gen spp. (30\%), and Pleuroncodes planipes (20\%) (Fig. 3f). Results of the NMDS and ANOSIM showed significant differences in both areas by maturity state (Fig. 5, Table 3 ).

The similarity percentages analysis (SIMPER) showed that the feeding dissimilarity between juveniles and adults in BCS was $83.72 \%$, and was due mainly to the variation in the rate of consumption of Pleuroncodes planipes (37.13\%), Loligo spp. (30.01\%), and species of
Lolliguncula (16.24\%). The observed trophic dissimilarity in the SIN region was $84.74 \%$, and it was attributed to Loligo spp. (40.20\%), Penaeus californiensis (25.70\%), and species of Lolliguncula (17.78\%).

Diet season. A total of 13 prey species were identified in 158 stomachs obtained during the cold season (38\%). According to the \%IRI the most important prey were Pleuroncodes planipes (59\%), Penaeus californiensis (38\%), and Loligo spp. (2\%) (Fig. 3g). A total of 33 prey species were identified in 257 stomachs from the warm season. According to the \%IRI the most important prey were Penaeus californiensis (58\%), Myodocopida gen spp. (31\%), and Loligo spp. (7\%) (Fig. 3h). There were significant differences in the diet by season in BCS but not in SIN (Fig. 5, Table 3). The feeding dissimilarity between seasons in BCS was $83.10 \%$, due to the almost exclusive consumption of Myodocopida gen spp. in the warm season. Myodocopida gen spp. represented $45.27 \%$ of trophic dissimilarity between seasons, whereas Pleuroncodes planipes and Penaeus californiensis represented $26.29 \%$ and $17.45 \%$, respectively.

Global data analysis. In this analysis we used one matrix of 12 sampling units (two locations by six categories) by 27 prey items. The correspondence analysis showed a clear separation between samples from SIN and from BCS, with the only exception being adults from SIN, who were placed close to the BCS group (Fig. 6). This separation was related to a higher consumption of prey such as Pleuroncodes planipes, Cynoscion parvipinnis Ayres, 1861, Squillidae gen spp., Glebocarcinus amphioetus, and Myodocopida gen spp. in specimens from BCS, whereas specimens from SIN were associated to a higher consumption of Ophichthus zophochir Jordan et Gilbert, 1882, Penaeus stylirostris, Penaeus vannamei, Balistes polylepis Steindachner, 1876, and Trachysalambria brevisuturae, Rimapenaeus faoe, Rimapenaeus pacificus (Table 1). Components 1 and 2 explained $90.68 \%$ of variation in the consumption of prey according to the studied variables. The MANOVA analysis showed that of all analysed variables (sex, size, and seasons) and their possible combinations, only size influenced significantly the difference in the diet of this species between SIN and BCS (Wilks' Lambda $=0.874, F_{4,258}=4.48, P=0.001$ ).

\section{DISCUSSION}

The results of this study confirm that Lutjanus peru is a predator that feeds preferentially on benthic organisms, but can also consume prey with pelagic habits. This suggests that this species has extensive feeding versatility, and that it has direct and indirect effects on a large number of trophic functional groups in the ecosystems that it inhabits.

Despite the large number of prey items identified in this species' diet (42), the trophic niche width suggests that its feeding behaviour is concentrated on a few prey items, especially shrimp, red pelagic crab, and ostracods, as had been reported in previous studies of this species and of other species of the family Lutjanidae (see Parrish 1987, Rojas and Chiappa 2002, Rojas et al. 2004, Guevara et al. 2007, Vázquez et al. 2008). 
Table 1

Minimum sample size by category of Pacific red snapper Lutjanus peru collected in Sinaloa and Baja California Sur

\begin{tabular}{|c|c|c|c|}
\hline Category & $N_{\mathrm{s}}$ & $N_{\mathrm{sm}}$ & $\mathrm{CV}$ \\
\hline$\overline{\text { SIN }}$ & 182 & 160 & 0.05 \\
\hline BCS & 233 & 136 & 0.05 \\
\hline Females & 231 & 138 & 0.05 \\
\hline Males & 184 & 76 & 0.05 \\
\hline Juveniles & 164 & 151 & 0.05 \\
\hline Adults & 251 & 70 & 0.05 \\
\hline Cold season & 158 & 152 & 0.05 \\
\hline Warm season & 257 & 150 & 0.05 \\
\hline
\end{tabular}

$N_{\mathrm{s}}=$ number of analysed stomachs, $N_{\mathrm{sm}}=$ minimum number of stomachs by category, $\mathrm{CV}=$ coefficient of variation for the respective sample size; $\mathrm{SIN}=$ Sinaloa, $\mathrm{BCS}=$ Baja California Sur.
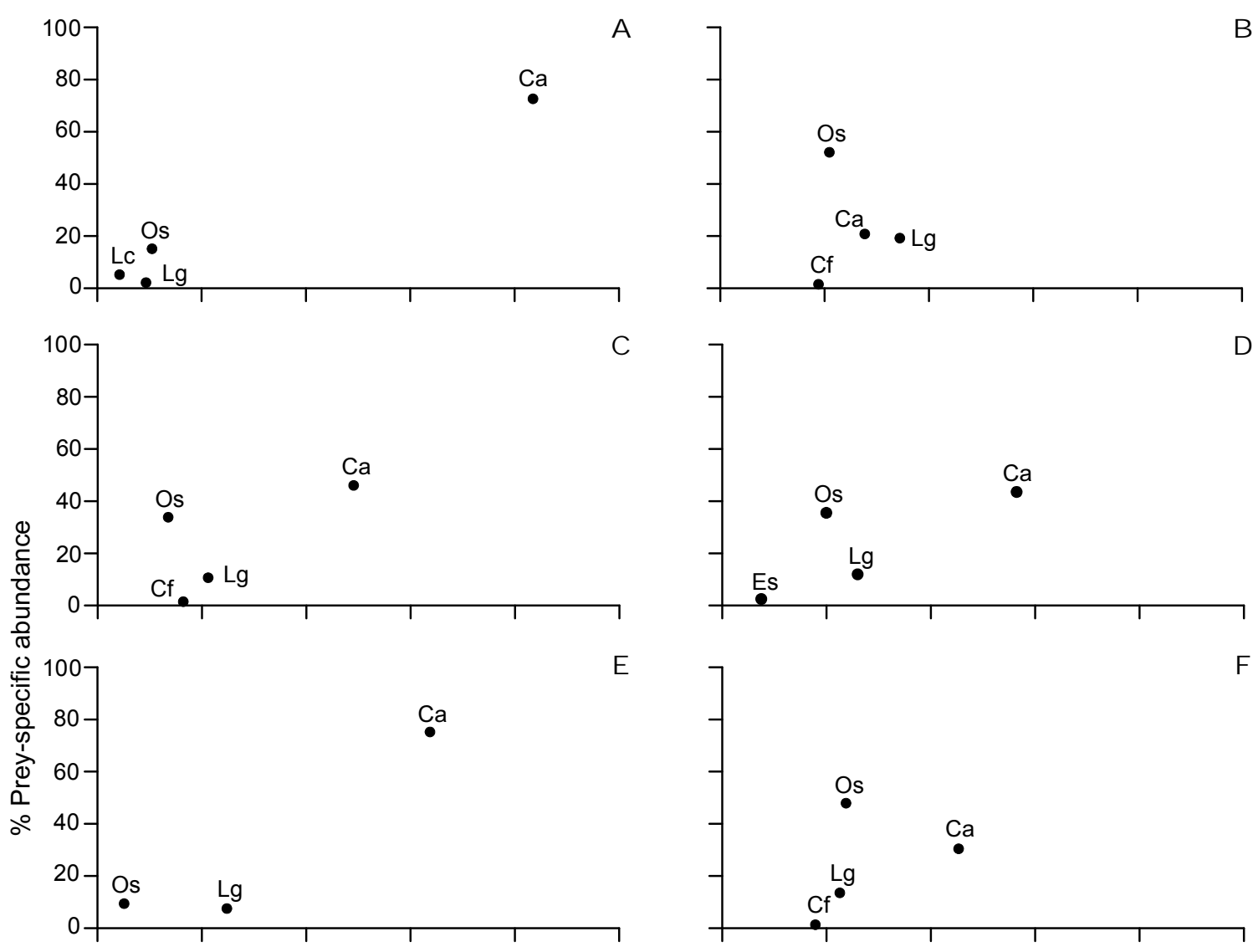

E
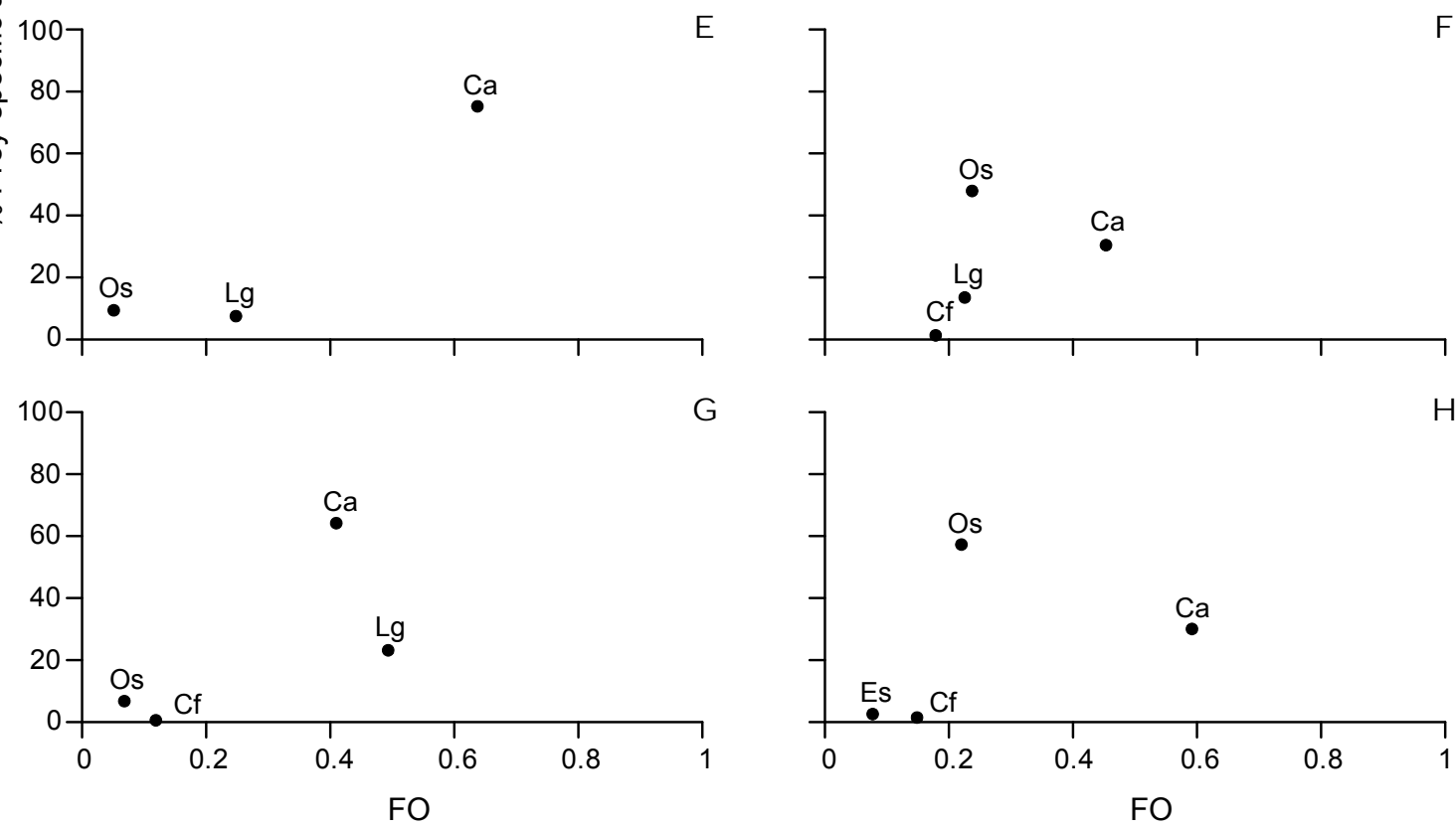

Fig. 4. Costello graph; Prey specific abundance $(\% N)$ of prey species by percentage frequency of occurrence $(\% F)$ in the general diet of Lutjanus peru; Sinaloa (A), Baja California Sur (B), females (C), males (D), juveniles (E), adults (F), cold season $(\mathbf{G})$, warm season $(\mathbf{H})$; Abbreviations for prey species: $\mathrm{Sh}=$ shrimps, Os $=$ ostracods, Pc $=$ pelagic red crab, $\mathrm{Sl}=$ shrimp larvae, $\mathrm{Cp}=$ cephalopods, $\mathrm{St}=$ stomatopods 
Table 2

Detailed characteristics of individual food components in the diet of Pacific red snapper, Lutjanus peru, collected in Sinaloa and Baja California Sur

\begin{tabular}{|c|c|c|c|c|c|c|c|c|c|c|c|c|c|c|c|c|c|}
\hline \multirow[t]{2}{*}{$\mathrm{T}$} & \multirow{2}{*}{ Prey item } & \multicolumn{8}{|c|}{ Sinaloa } & \multicolumn{8}{|c|}{ Baja California Sur } \\
\hline & & $N$ & $\% N$ & $W$ & $\% W$ & $F$ & $\% F$ & IRI & $\%$ IRI & $N$ & $\% N$ & $W$ & $\% W$ & $F$ & $\% F$ & IRI & $\%$ IRI \\
\hline \multirow[t]{2}{*}{ B } & Psammotreta grandis & 4 & 0.25 & 2 & 0.27 & 3 & 1.65 & 0.85 & 0.03 & 8 & 0.27 & 0.95 & 0.05 & 3 & 1.29 & 0.41 & 0.01 \\
\hline & $\begin{array}{l}\text { Berryteuthis } \\
\text { anonychus }\end{array}$ & & & & & & & & & 1 & 0.03 & 2 & 0.11 & 1 & 0.43 & 0.06 & 0.00 \\
\hline \multirow[t]{4}{*}{$\mathrm{C}$} & Loligo spp. & 9 & 0.55 & 190.5 & 25.70 & 9 & 4.95 & 129.85 & 4.69 & 32 & 1.08 & 407.50 & 22.03 & 29 & 12.45 & 287.69 & 7.11 \\
\hline & $\begin{array}{l}\text { Lolliguncula } \\
\text { diomedeae }\end{array}$ & 3 & 0.18 & 78 & 10.52 & 2 & 1.10 & 11.77 & 0.42 & 6 & 0.20 & 138.50 & 7.49 & 6 & 2.58 & 19.81 & 0.49 \\
\hline & $\begin{array}{l}\text { Lolliguncula } \\
\text { panamensis }\end{array}$ & & & & & & & & & 8 & 0.27 & 195 & 10.54 & 5 & 2.15 & 23.21 & 0.57 \\
\hline & Paroctopus digueti & 3 & 0.18 & 11 & 1.48 & 3 & 1.65 & 2.75 & 0.10 & 3 & 0.10 & 9.5 & 0.51 & 3 & 1.29 & 0.79 & 0.02 \\
\hline \multirow[t]{2}{*}{ G } & Natica spp. & 2 & 0.12 & 0.75 & 0.10 & 2 & 1.10 & 0.25 & 0.01 & & & & & & & & \\
\hline & Trochidae gen. spp. & 1 & 0.06 & 0.25 & 0.03 & 1 & 0.55 & 0.05 & 0.00 & & & & & & & & \\
\hline \multirow[t]{20}{*}{ M } & $\begin{array}{l}\text { Glebocarcinus } \\
\text { amphioetus }\end{array}$ & 5 & 0.31 & 3 & 0.40 & 2 & 1.10 & 0.78 & 0.03 & & & & & & & & \\
\hline & Elthusa vulgaris & 3 & 0.18 & 6.8 & 0.92 & 3 & 1.65 & 1.82 & 0.07 & 2 & 0.07 & 8.5 & 0.46 & 2 & 0.86 & 0.45 & 0.01 \\
\hline & $\begin{array}{l}\text { Petrochirus } \\
\text { californiensis }\end{array}$ & 1 & 0.06 & 0.5 & 0.07 & 1 & 0.55 & 0.07 & 0.00 & & & & & & & & \\
\hline & Pleuroncodes planipes & 58 & 3.58 & 35.6 & 4.80 & 17 & 9.34 & 78.27 & 2.82 & 574 & 19.38 & 564.80 & 30.54 & 80 & 34.33 & 1713.94 & 42.38 \\
\hline & Ocypode spp. & 1 & 0.06 & 3 & 0.40 & 1 & 0.55 & 0.26 & 0.01 & 1 & 0.03 & 0.5 & 0.03 & 1 & 0.43 & 0.03 & 0.00 \\
\hline & Eurypanopeus spp. & 1 & 0.06 & 4 & 0.54 & 1 & 0.55 & 0.33 & 0.01 & 1 & 0.03 & 1 & 0.05 & 1 & 0.43 & 0.04 & 0.00 \\
\hline & Penaeus brevirostris & 23 & 1.42 & 8.6 & 1.16 & 6 & 3.30 & 8.50 & 0.31 & & & & & & & & \\
\hline & Penaeus californiensis & 589 & 36.31 & 225.1 & 30.37 & 55 & 30.22 & 2015.20 & 72.72 & 588 & 19.85 & 238.10 & 12.87 & 57 & 24.46 & 800.59 & 19.80 \\
\hline & Penaeus spp. & & & & & & & & & 7 & 0.24 & 0.50 & 0.03 & 1 & 0.43 & 0.11 & 0.00 \\
\hline & Penaeus stylirostris & 147 & 9.06 & 28 & 3.78 & 12 & 6.59 & 84.66 & 3.06 & 21 & 0.71 & 83 & 4.49 & 7 & 3.00 & 15.61 & 0.39 \\
\hline & Penaeus vannamei & 9 & 0.55 & 9 & 1.21 & 2 & 1.10 & 1.94 & 0.07 & & & & & & & & \\
\hline & $\begin{array}{l}\text { Trachysalambria } \\
\text { brevisuturae }\end{array}$ & 30 & 1.85 & 10 & 1.35 & 3 & 1.65 & 5.27 & 0.19 & & & & & & & & \\
\hline & Rimapenaeus faoe & 107 & 6.60 & 11.5 & 1.55 & 5 & 2.75 & 22.39 & 0.81 & & & & & & & & \\
\hline & Rimapenaeus pacificus & & & & & & & & & 3 & 0.10 & 1 & 0.05 & 1 & 0.43 & 0.07 & 0.00 \\
\hline & Xiphopenaeus riveti & 2 & 0.12 & 1 & 0.13 & 1 & 0.55 & 0.14 & 0.01 & & & & & & & & \\
\hline & $\begin{array}{l}\text { Squilla aculeata } \\
\text { aculeata }\end{array}$ & & & & & & & & & 5 & 0.17 & 9 & 0.49 & 3 & 1.29 & 0.84 & 0.02 \\
\hline & Squilla biformis & 1 & 0.06 & 3 & 0.40 & 1 & 0.55 & 0.26 & 0.01 & 2 & 0.07 & 5 & 0.27 & 1 & 0.43 & 0.15 & 0.00 \\
\hline & Squilla bigelowi & 1 & 0.06 & 2 & 0.27 & 1 & 0.55 & 0.18 & 0.01 & 1 & 0.03 & 1 & 0.05 & 1 & 0.43 & 0.04 & 0.00 \\
\hline & Squilla mantoidea & 13 & 0.80 & 10 & 1.35 & 4 & 2.20 & 4.73 & 0.17 & 55 & 1.86 & 16.50 & 0.89 & 7 & 3.00 & 8.26 & 0.20 \\
\hline & Squilla spp. & 7 & 0.43 & 2.5 & 0.34 & 4 & 2.20 & 1.69 & 0.06 & 3 & 0.10 & 12 & 0.65 & 3 & 1.29 & 0.97 & 0.02 \\
\hline \multirow[t]{4}{*}{$\mathrm{O}$} & Myodocopida gen. spp. & 401 & 24.72 & 10.6 & 1.43 & 19 & 10.44 & 273.02 & 9.85 & 1545 & 52.16 & 46.60 & 2.52 & 49 & 21.03 & 1149.93 & 28.44 \\
\hline & Shrimp larvae & 135 & 8.32 & 4.9 & 0.66 & 8 & 4.40 & 39.49 & 1.43 & 44 & 1.49 & 1.30 & 0.07 & 5 & 2.15 & 3.34 & 0.08 \\
\hline & Crab larvae & 5 & 0.31 & 2 & 0.27 & 3 & 1.65 & 0.95 & 0.03 & & & & & & & & \\
\hline & Crustacean remains & 0 & 0.00 & 29.4 & 3.97 & 20 & 10.99 & 43.59 & 1.57 & 0 & 0.00 & 17 & 0.92 & 14 & 6.01 & 5.52 & 0.14 \\
\hline \multirow[t]{11}{*}{ A } & Balistes polylepis & 1 & 0.06 & 2 & 0.27 & 1 & 0.55 & 0.18 & 0.01 & & & & & & & & \\
\hline & Selene brevoortii & & & & & & & & & 1 & 0.03 & 1 & 0.05 & 1 & 0.43 & 0.04 & 0.00 \\
\hline & Harengula thrissina & & & & & & & & & 1 & 0.03 & 2 & 0.11 & 1 & 0.43 & 0.06 & 0.00 \\
\hline & Anchoa spp. & & & & & & & & & 5 & 0.17 & 41 & 2.22 & 4 & 1.72 & 4.10 & 0.10 \\
\hline & Ophichthus zophochir & 15 & 0.92 & 24 & 3.24 & 10 & 5.49 & 22.87 & 0.83 & 5 & 0.17 & 4.50 & 0.24 & 5 & 2.15 & 0.88 & 0.02 \\
\hline & Cynoscion parvipinnis & & & & & & & & & 7 & 0.24 & 14.80 & 0.80 & 4 & 1.72 & 1.78 & 0.04 \\
\hline & Sebastes spp. & & & & & & & & & 3 & 0.10 & 2.50 & 0.14 & 2 & 0.86 & 0.20 & 0.01 \\
\hline & Fish remains & 0 & 0 & 7.25 & 0.98 & 6 & 3.30 & 3.22 & 0.12 & 0 & 0.00 & 13.35 & 0.72 & 10 & 4.29 & 3.10 & 0.08 \\
\hline & Fish eggs & 45 & 2.77 & 1 & 0.13 & 4 & 2.20 & 6.39 & 0.23 & 30 & 1.01 & 0.70 & 0.04 & 2 & 0.86 & 0.90 & 0.02 \\
\hline & UOM & 0 & 0 & 13.9 & 1.88 & 9 & 4.95 & 9.27 & 0.33 & 0 & 0 & 10.30 & 0.56 & 4 & 1.72 & 0.96 & 0.02 \\
\hline & TOTAL & 1622 & 100 & 741.2 & 100 & 182 & 120.3 & 2771.02 & 100 & 2962 & 100 & 1849.40 & 100 & 233 & 134.33 & 4043.87 & 100 \\
\hline
\end{tabular}

$\mathrm{T}=$ taxon, $\mathrm{B}=$ Bivalvia, $\mathrm{C}=$ Cephalopoda, $\mathrm{G}=$ Gastropoda, $\mathrm{M}=$ Malacostraca, $\mathrm{O}=$ Ostracoda, $\mathrm{A}=$ Actinopterygii; $N=$ number, $W=$ weight, $F=$ frequency of occurrence, IRI $=$ index of relative importance (absolute values); $\% N, \% W, \% F, \% I R I$ are respective percentage values; $\mathrm{UOM}=$ unidentified organic matter. 

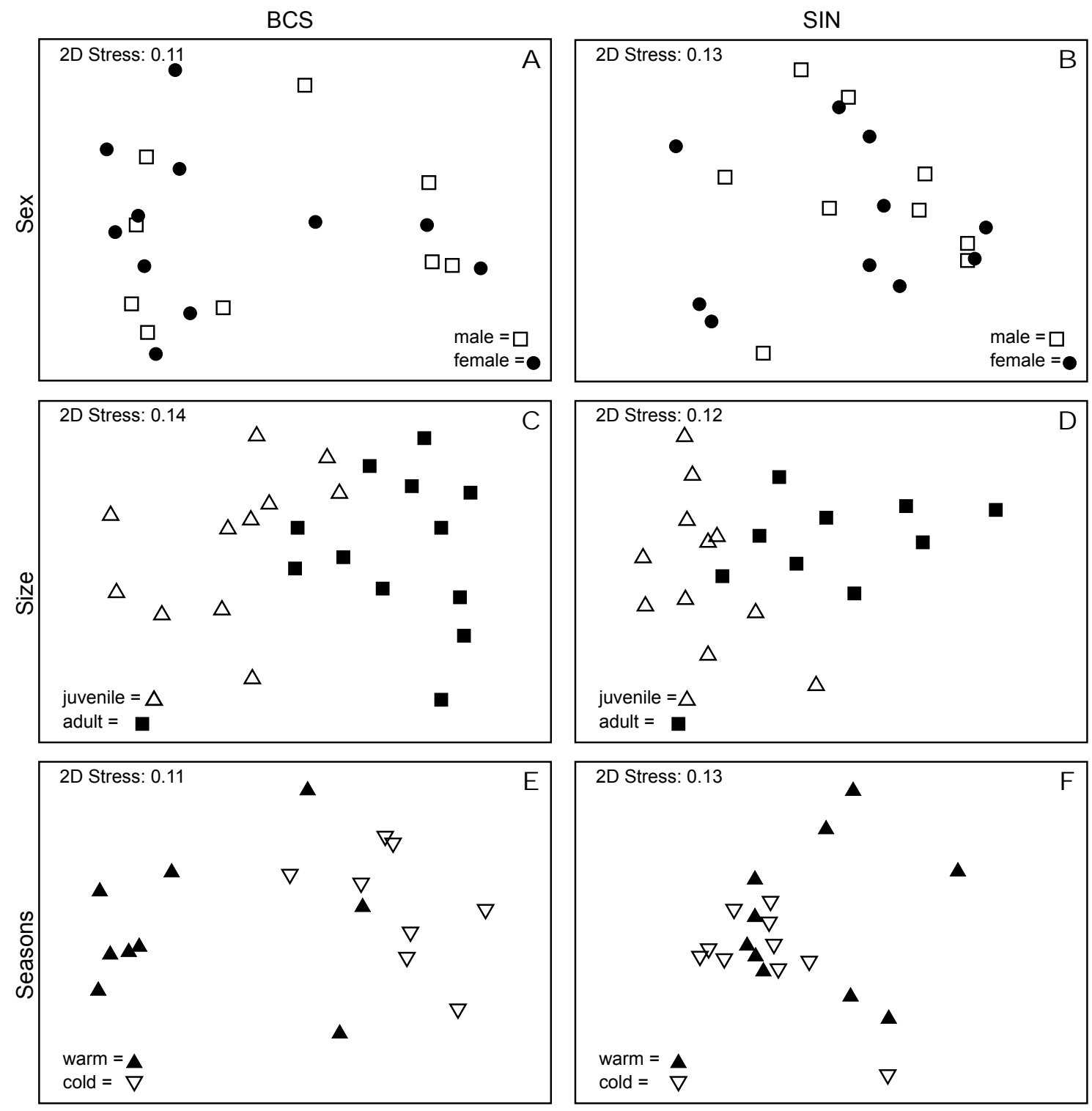

Fig. 5. Non-metric multidimensional scaling analysis (NMDS) of percent weight $(\% W)$ data in the diet of Lutjanus peru from the two sampling locations in the southern Gulf of California, based on sex, size, and location

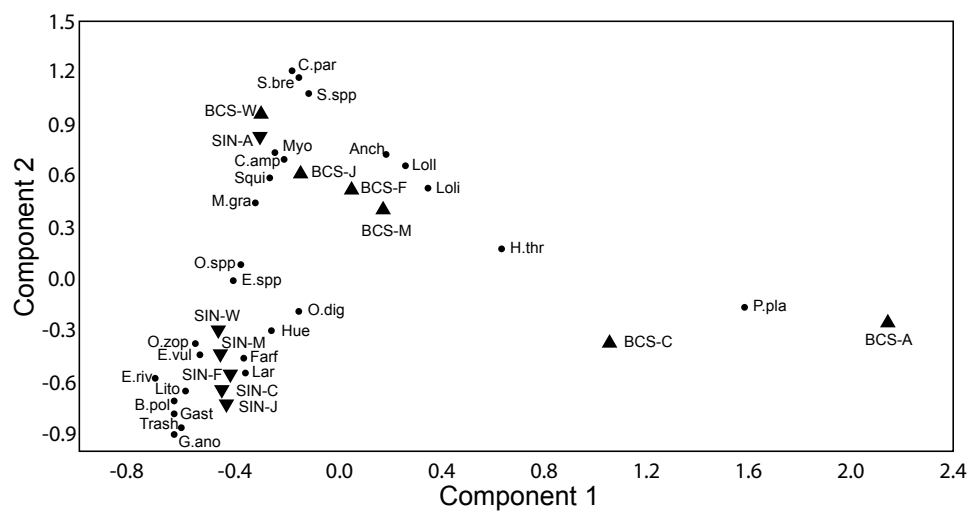

Fig. 6. Correspondence analysis between diet (prey items) and sex, size, and the sampling area of Lutjanus peru from the two sampling locations in the southern Gulf of California; The first axis explained $70.5 \%$ of the variation in the diet and the second axis accounted for 20.18\%; Abbreviations: $\mathrm{M}=$ male, $\mathrm{F}=$ female, $\mathrm{J}=$ juveniles, $\mathrm{A}=$ adults, $\mathrm{C}=$ cold season, $\mathrm{W}=$ warm season, $\mathrm{SIN}=$ Sinaloa, $\mathrm{BCS}=$ Baja California Sur 
Table 3 to the temporal availability of each resource. Penaeus

$R$ and $P$ significance values for diet similarity analyses (Analysis of similarities [ANOSIM]) between sexes, sizes and among seasons of Pacific red snapper Lutjanus peru collected in Baja California Sur and Sinaloa of in BCS and SIN

\begin{tabular}{lcccc}
\hline & \multicolumn{2}{c}{ Baja California Sur } & \multicolumn{2}{c}{ Sinaloa } \\
\hline Variable & $\mathrm{R}$ & $\mathrm{P}$ & $\mathrm{R}$ & $\mathrm{P}$ \\
Sex & -0.058 & 0.78 & -0.062 & 0.75 \\
Size & 0.197 & $0.001^{\mathrm{s}}$ & 0.178 & $0.04^{\mathrm{s}}$ \\
Seasons & 0.464 & $0.002^{\mathrm{s}}$ & 0.027 & 0.25 \\
\hline
\end{tabular}

$\mathrm{s}=$ significant values for diet similarity analyses.

This trophic behaviour could be due to the high abundance of those prey species in the study area (Aurioles 1992, Barbosa et al. 2012). Some authors have catalogued snapper as opportunistic predators that take advantage of available resources (Yáñez and Nugent 1977, Parrish 1987, Vázquez et al. 2008). Díaz (unpublished*) reported that in La Paz Bay Lutjanus peru fed mainly on urochordates, while Lutjanus argentiventris (Peters, 1869) fed mainly on fish eggs (Vázquez et al. 2008), which suggests that these species take advantage of available resources in their habitat and have therefore high trophic plasticity.

Given that males and females consumed shrimp, red pelagic crab, and ostracods in similar proportions, we did not find an effect of sex on the diet of this predator. This feeding pattern has been reported for this and other species (Saucedo-Lozano et al. 1999, Santamaría et al. 2003, Chiappa et al. 2004, Saucedo Lozano et al. 2006), and it has been suggested that it is due to a lack of sexual segregation and to gregarious behaviour (Rojas 1997, Ruíz et al. 1985, Santamaría et al. 2003).

The size at sexual maturity of the species was the most important variable in the feeding differences within and between regions. Like several snapper species (Rojas and Chiappa 2002, Santamaría et al. 2003, Rojas et al. 2004, Guevara et al. 2007, Oliveira et al. 2011, Díaz unpublished*), it was found that as individuals of this species increase in size they incorporate a greater quantity of fish in their diet, because they acquire greater abilities to hunt prey with greater mobility such as fish (SaucedoLozano 1999, Santamaría et al. 2003, Yan et al. 2012). This strategy has been identified as a potential strategy of predators to reduce competition and increase the coexistence of competitors (Zaret and Rand 1971, Ross 1986, Platell and Potter 2001, Navia et al. 2007).

Differences in the diet of the Pacific red snapper, Lutjanus peru, were also detected by season. During the warm season this species fed mainly on Penaeus californiensis, whereas during the cold season there was a high consumption of Pleuroncodes planipes, due californiensis is a shrimp that is available year-round (Sierra et al. 2000, Madrid et al. unpublished ${ }^{* *}$ ); however, it is most abundant from March to June, which is when it has its reproductive peak (Manzano et al. 2007). The pelagic red crab Pleuroncodes planipes has maximum abundance during the winter off the western coast of Baja California (Aurioles 1992); it inhabits mainly coastal areas, and is associated to upwellings (Alvariño 1976, Aurioles et al. 1995, Aurioles and Pérez 1997). This behaviour coincides with what has been reported by some authors for L. peru, with differences in diet being described during the dry or wet seasons in other areas of the Mexican Pacific (Saucedo-Lozano et al. 1999, Santamaría et al. 2003).

The differences in diet of Lutjanus peru, by region are due to the higher consumption of Penaeus californiensis in $\mathrm{SIN}$ and of Pleuroncodes planipes in BCS. This variation may be related to the availability and abundance of these prey species in each region. The SIN area is dominated by sandy and muddy substrates, a wide continental platform, large mangrove areas, and productive coastal lagoons (Amador et al. 2003). These characteristics facilitate the settlement and growth of benthic invertebrates, among which are shrimp, which represent the highest biomass percent of invertebrates in the region (Anonymous 2012).

The substrate is mainly rocky with a reduced continental platform in the BCS region (Obeso et al. 2004, Rodríguez et al. 2005). The wind patterns generate highly productive upwellings that favour the development of pelagic invertebrates (Obeso et al. 2004). Among these species is Pleuroncodes planipes, which reaches biomass values that are so significant ( $>460000 \mathrm{t}$, Aurioles et al. 1995) that it is considered an important food item in the diet of bony fishes, sharks, sperm whales and sea turtles (Sánchez unpublished ${ }^{* * *}$ ).

From the results of the presently reported study it can be inferred that the Pacific red snapper, Lutjanus peru, plays a similar trophic role in the two studied regions, because in both areas it consumed mainly benthic crustaceans and fish. It should be noted that this species' ontogenetic changes at the two locations result in it playing two different trophic roles during its life history, as juveniles and as adults. This increases the ecological value of this species through redundancy and formation of trophic guilds (Navia et al. 2012), in both the SIN and BCS trophic webs. It should also be noted that as this species acts as an intermediary in the energy flow from lower levels towards top predators (Arreguín and Manickchand 1998), and also has an important role in the structure of marine trophic webs (Navia et al. 2016). The need to carry out management and regulation actions that guarantee the permanence of this species in the studied ecosystems is emphasized.

\footnotetext{
* Díaz U.J.G. 1994. Análisis trofodinámico del huachinango, Lutjanus peru, en las bahías de la Paz y la Ventana., B.C.S., México. Tesis de Maestría en Ciencias, Centro de Investigación Científica y de Educación Superior, Ensenada, Baja California, México.

** Madrid V.J., Chávez D., Melchor J.M. 2001. Situación actual de las poblaciones de camarón café (Farfantepenaeus californiensis), en las costas de Sinaloa y norte de Nayarit, México. Documento Técnico. INAPESCA-CRIP- Mazatlán, Sinaloa, México.

*** Sánchez A.D. 2001. Depredación diferencial sobre la langostilla Pleuroncodes planipes (Crustacea: Galatheidae) por tres especies ícticas dominantes en los fondos blandos de la costa oeste de Baja California Sur. Tesis de Licenciatura en Biología Marina, Universidad Autónoma de Baja California Sur. 81 pp.
} 


\section{ACKNOWLEDGEMENTS}

The authors are grateful for economic support provided by the projects SIP-IPN (20141240). XGMS thanks the Instituto Politécnico Nacional (IPN) for economic support through the Contratación por Excelencia Program. XGMS, LAAC and BSG are grateful for support received through COFAA and EDI. JSRP received a scholarship from EDA-UAS and appreciates the support given by the project CONACyT 231525. This project was made possible by agreements made through the Red Interinstitucional para la Evaluación, Manejo and Aprovechamiento de los Recursos Acuáticos (RIEMARA).

\section{REFERENCES}

Allen G.R. 1985. Snappers of the world. An annotated and illustrated catalogue of Lutjanid species known to date. FAO Fisheries Synopsis 125 (6): 1-208.

AlvariñoA. 1976. Distribución batimétrica de Pleuroncodes planipes (Stimpson) (Crustáceo: Galatheidae). Pp. 266285. In: Memorias sobre la Biología Marina y Dinámica Poblacional de Camarones, Guaymas, Son. México.

Amador B.A., Trasviña C.A., Muhlia M.A., Argote M.L. 2003. Influence of EBES seamount and Farallon basin on coastal circulation in the Gulf of California, Mexico. Geofísica Internacional 42 (3): 407-418.

Amundsen P.A., Gabler H.M., Staldvik F.J. 1996. A new approach to graphical analysis of feeding strategy from stomach contents data modification of the Costello (1990) method. Journal of Fish Biology 48 (4): 607-614. DOI: $10.1111 / \mathrm{j} .1095-8649.1996 . t b 01455 . x$

Anonymous 2012. Anuario estadístico de Acuacultura y Pesca 2012. SAGARPA, Mexico.

Arreguín S.F., Manickchand H.S. 1998. The trophic role of lutjanid fish and impacts of their fisheries in two ecosystems in the Gulf of Mexico. Journal of Fish Biology 53 (Suppl. A): 143-153.

DOI: $10.1111 / \mathrm{j} .1095-8649.1998 . t b 01024 . x$

Aurioles G.D. 1992. Inshore offshore movements of pelagic red crabs Pleuroncodes planipes (Decapoda: Anomura: Galatheidae) off the Pacific coast of Baja California Sur, Mexico. Crustaceana 62 (1): 71-84. DOI: $10.1163 / 156854092 X 00064$

Aurioles G.D., Balart E.F., Castro J.L. 1995. Recomendaciones para la explotación y aprovechamiento de la langostilla. Pp. 221-233. In: Aurioles G.D., Balart E.F. (eds.) La langostilla, biología, ecología y aprovechamiento. Centro de investigaciones Biológicas del Noroeste. La Paz, Baja California Sur, México.

Aurioles-Gamboa D., Pérez-Flores R. 1997. Seasonal and bathymetric changes in feeding habits of the benthic crab Pleuroncodes planipes (Decapoda, Anomura, Galatheidae) off the Pacific coast of Baja California Sur, México. Crustaceana 70 (3): 272-287.

Barbosa S.L., Díaz P.J., Uribe M. 2012. Variación morfológica del camarón café (Farfantepenaeus californiensis) en el Pacífico mexicano. Revista Mexicana de Biodiversidad 83 (1): 42-50.
Blaber S.M., Bulman C.M. 1987. Diets of fishes of the upper continental slope of eastern Tasmania: content, calorific values, dietary overlap and trophic relationships. Marine Biology 95 (3): 345-356.

Chiappa C.X., Rojas H.A., Mascaro M. 2004. Coexistencia de Lutjanus peru y Lutjanus guttatus (Pisces: Lutjanidae) en la costa de Guerrero, México: relación con la variación temporal en el reclutamiento. Revista de Biología Tropical 52 (1): 177-185.

Clarke K.R. 1993. Non-parametric multivariate analyses of changes in community structure. Australian Journal of Ecology 18 (1) 117-143.

Clarke K.R., Gorley R.N. 2006. PRIMER v6 User Manual/Tutorial. Primer-E, Plymouth, UK.

Colwell R.K. 2009. EstimateS: Statistical estimation of species richness and shared species from samples. Version 8.2. http://viceroy.eeb.uconn.edu/estimates

Costello M.J. 1990. Predator feeding strategy and prey importance: a new graphical analysis. Journal of Fish Biology 36 (2): 261-263. DOI: $10.1111 /$ j.1095-8649.1990.tb05601.x

Cruz R.M., Chávez E.A., Espino E., García A. 1996. Assessment of a snapper complex (Lutjanus spp.) of the eastern tropical Pacific. In: Arreguín-Sanchez F., Munro J.L., Balgos M.C., Pauly D. (eds.) Biology, fisheries and culture of tropical groupers and snappers. Campeche, Mexico. ICLARM Conference Proceedings 48: 324-330.

Dale J.J., Wallsgrove N.J., Popp B.N., Holland K. 2011. Nursery habitat use and foraging ecology of the brown stingray Dasyatis lata determined from stomach contents, bulk and amino acid stable isotopes. Marine Ecology Progress Series 433: 221-236.

Ferreri R., Basilone G., D'Elia M., Traina A., SaboridoRey F., Mazzola S. 2009. Validation of macroscopic maturity stages according to microscopic histological examination for European anchovy. Marine Ecology 30: $181-187$.

DOI: $10.1111 /$ j.1439-0485.2009.00312.x

Froese R., Pauly D. (eds.) 2016. FishBase. [Version 01/2016] www.fishbase.org

Graham J.H., Vrijenhoek R.C. 1988. Detrended correspondence analysis of dietary data. Transactions of the American Fisheries Society 117 (1): 29-36.

Griffiths S.P., Kuhnert P.M., Fry G.F., Manson F.J. 2009. Temporal and size-related variation in the diet, consumption rate, and daily ration of mackerel tuna (Euthynnus affinis) in neritic waters of eastern Australia. ICES Journal of Marine Science 66: 720 733.

Guevara E., Álvarez H., Mascaro M., Rosas C., Sánchez A. 2007. Hábitos alimenticios y ecología trófica del pez Lutjanus griseus (Pisces: Lutjanidae) asociado a la vegetación sumergida en la Laguna de Términos, Campeche, México. Revista de Biología Tropical 55 (3-4): 989-1004.

DOI: $10.15517 /$ rbt.v55i3-4.5972 
Guevara-Guillén C., Shirasago-Germán B., PérezLezama E.L. 2015. The influence of large-scale phenomena on La Paz Bay hydrographic variability. Open Journal of Marine Science 5 (1): 146-157.

DOI: $10.4236 /$ ojms.2015.51012

Hernández L.P., Motta P.J. 1997. Trophic consequences of differential performance: ontogeny of oral jawcrushing performance in the sheepshead, Archosargus probatocephalus (Teleostei: Sparidae). Journal of Zoology 243 (4): 737-756.

DOI: 10.1111/j.1469-7998.1997.tb01973.x

Hernández-Aguilar S.B., Abitia-Cárdenas L.A., Moreno-Sánchez X.G., Arrellano Martínez M., González-Rodríguez E. 2013. Trophic spectrum of the sailfish Istiophorus platypterus caught off Acapulco in the southern Mexican Pacific. Journal of the Marine Biological Association of the United Kingdom 93 (4): 1097-1104.

DOI: $10.1017 / \mathrm{S} 0025315412001622$

Hyslop E.J. 1980. Stomach contents analysis a review of methods and their application. Journal of Fish Biology 17: 411-429.

DOI: $10.1111 / \mathrm{j} .1095-8649.1980 . t b 02775 . x$

Jiménez-Valverde A., Hortal J. 2003. Las curvas de acumulación de especies y la necesidad de evaluar la calidad de los inventarios biológicos. Revista Ibérica de Aracnología 8:151-161.

Lavín M.F., Marinone S.G. 2003. An overview of the physical oceanography of the Central Gulf of California. Pp.173-204. In: Velasco-Fuentes O.U., Sheinbaum J., Ochoa de la Torre J.L. (eds.) Nonlinear Processes in Geophysical Fluid Dynamics. Kluwer Academic Publishers, Dordrecht, the Netherlands. DOI: 10.1007/978-94-010-0074-1

Magurran A.E. 1988. Ecological diversity and its measurement. Princeton University Press, Princeton, NJ, USA.

Manzano S.M., Aragón N.E., Salinas C.A., Lluch D.B. 2007. Distribution and abundance of penaeid shrimps in a hypersaline laggon in northwestern Mexico, emphasizing the brown shrimp Farfantepenaeus californiensis life cycle. Marine Biology 152 (5): 1021-1029.

Marshall A.D., Kyne P.M., Bennett M.B. 2008. Comparing the diet of two sympatric urolophid elasmobranchs (Trygonoptera testacea Müller and Henle and Urolophus kapalensis Yearsley \& Last): Evidence of ontogenetic shifts and possible resource partitioning. Journal of Fish Biology 72 (4): 883-898. DOI: $10.1111 /$ j.1095-8649.2007.01762.x

Moreno-Sánchez X.G., Palacios-Salgado D.S., Abitia-Cardenas L.A., Navia A.F. 2015. Diet of the yellowfinsnook, Centropomusrobalito(Actinopterygii: Perciformes: Centropomidae), in the Southwestern Gulf of California. Acta Ichthyologica et Piscatoria 45 (1): 21-29 DOI: 10.3750/AIP2015.45.1.03

Muto E.Y., Soares L.S.H., Goitein R. 2001. Food resource utilization of the skates Rioraja agassizii (Müller and Henle, 1841) and Psammobatis extenta
(Garman, 1913) on the continental shelf off Ubatuba, South-Eastern Brazil. Revista Brasileira de Biologia 61 (2): 217-238.

DOI: $10.1590 / \mathrm{S} 0034-71082001000200005$

Navia A.F., Cruz V.H., Giraldo A., Barausse A. 2016. Structural analysis of a marine tropical food web: a useful approach for ecosystem management? Ecological Modelling 328: 23-33.

DOI: $10.1016 /$ j.ecolmodel.2016.02.009

Navia A.F., Cruz-Escalona V.H., Cortés E., Jordán F., Mejía-Falla P. 2012. [18] Changes to marine trophic networks caused by fishing. Pp. 417-452. In: Mahamane, A. (ed.) Diversity of Ecosystems. In Tech Press, Croatia.

Navia A.F., Mejía P.A., Giraldo A. 2007. Feeding ecology of elasmobranchs fishes captured in the central fishing zone of the Colombian Eastern Tropical Pacific. BMC Ecology 7: 8.

DOI: $10.1186 / 1472-6785-7-8$

Obeso N.M., Shirasago B., Sánchez L., Gaviño J.H. 2004. Hydrographic variability in Bahia de La Paz, B.C.S., México during the 1997-1998 El Niño. Deep Sea Research Part II. 51 (6-9): 689-710. DOI: $10.1016 /$ j.dsr2.2004.05.005

Oliveira F.M., Abilhoa V., Hoffmann G.D.C.S. 2011. Feeding ecology of Lutjanus analis (Teleostei: Lutjanidae) from Abrolhos Bank, Eastern Brazil. Neotropical Ichthyology 9 (2): 411-418. DOI: $10.1590 /$ S1679-62252011005000022

Parrish J.D. 1987. The trophic biology of snapper and grouper. Pp. 405-463. In: Polovina, J.J., Ralston S. (eds.) Tropical snapper and groupers: Biology and fisheries management. Westview Press. Boulder CO, USA.

Pinkas L., Oliphant S.M., Iverson K.L. 1971. Food habits of albacore, bluefin tuna, and bonito in California waters. California Department of Fish and Game. Fish Bulletin No. 152.

Platell M.E., Potter I.C. 2001. Partitioning of food resources among 18 abundant benthic carnivorous fish species in marine waters of the lower west coast of Australia. Journal of Experimental Marine Biology and Ecology 261 (1): 31-54.

DOI: $10.1016 / \mathrm{S} 0022-0981(01) 00257-\mathrm{X}$

Rinewalt C.S., Ebert D.A., Cailliet G.M. 2007. Food habits of the sandpaper skate, Bathyraja kincaidii (Garman, 1908) off central California: Seasonal variation in diet linked to oceanographic conditions. Environmental Biology of Fishes 80 (2): 147-163.

DOI: $10.1007 / \mathrm{s} 10641-007-9218-5$

Rodríguez R.J., Galván M.F., Muhlia M.A., Gutiérrez S.F., Gracia L.V. 2005. Fish assemblages around Espiritu Santo Island and Espiritu Santo Seamount in the lower Gulf of California, México. Bulletin of Marine Science 77 (1): 33-50.

Rojas M.J. 1997. Dieta del "pargo colorado" Lutjanus colorado (Pisces: Lutjanidae) en el Golfo de Nicoya, Costa Rica. Revista de Biología Tropical 45 (3): 1173 1183. 
Rojas H.A.A., Chiappa C.X. 2002. Feeding habits of the spotted rose snapper Lutjanus guttatus (Pisces: Lutjanidae) in the coast of Guerrero, México. Ciencias Marinas 28 (2): 133-147.

DOI: $10.7773 / \mathrm{cm} . v 28 \mathrm{i} 2.219$

Rojas R., Maravilla E., Chicas F. 2004. Hábitos alimentarios del pargo manchado Lutjanus guttatus (Pisces: Lutjanidae) en Los Cobanos y Puerto La Libertad, El Salvador. Revista de Biología Tropical 52 (1): 163-170.

Ross S.T. 1986. Resource partitioning in fish assemblages: a review of field study. Copeia 1986 (2): 352-388.

Ruíz L.A., Girón B.E., Madrid V.J., González B.A. 1985. Determinación de edad, crecimiento y algunas constantes biológicas del huachinango del Pacífico, Lutjanus peru (Nichols y Murphy 1922). Pp. 188-201. In: Morelia Michoacán. Memorias VIII Congreso Nacional de Zoología, México.

Santamaría M.A., Elorduy G.J., Rojas A.H. 2003. Hábitos alimentarios de Lutjanus peru (Pisces: Lutjanidae) en las costas de Guerreo, México. Revista de Biología Tropical 51 (2): 503-518.

Saucedo-Lozano M., González-Sansón G., ChiappaCarrara X. 1999. Alimentación natural de juveniles de Lutjanus peru (Nichols y Murphy, 1922) (Lutjanidae: Perciformes) en la costas de Jalisco y Colima, México. Ciencias Marinas 25 (3): 381-400.

Saucedo Lozano M., Raymundo Huizar A.R., Valadez González C. 2006. Comparación de los hábitos alimentarios de juveniles de Lutjanus peru y Lutjanus guttatus en la Costa de Jalisco y Colima, México. Pp. 209-218. In: Jiménez-Quiroz M.C., Espino-Barr E. (eds.) Los recursos pesqueros y acuícolas de Jalisco, Colima y Michoacán. INP. SAGARPA. México.

Sierra R.P., Acosta C.C., García B.J.A., García J.A.R., Liedo G.A., Melchor A.J.M., Ramos C.S., Rosas C.A., Toledo D.M.P., Zarate B.E. 2000. Camarón, Pesquerías del Océano Pacífico. Pp. 1-50. In: Cisneros-Mata MA, Beléndez-Moreno L.F.,
Zárate-Becerra E. (eds.), Sustentabilidad y Pesca Responsable en México: Evaluación y Manejo 19992000. INAPESCA, SEMARNAT, México.

Vázquez S.R.I., Rodríguez R.J., Abitia C.L.A., Galvan M.F. 2008. Food habits of the yellow snapper Lutjanus argentiventris (Peters, 1869) (Percoidei: Lutjanidae) in La Paz Bay, México. Revista de Biología Marina y Oceanografía 43 (2): 295-302.

Wetherbee M.B., Cortés E., Bizarro J.J. 2012. Food consumption and feeding habits. Pp. 223-244. In: Carrier J.C., Musick J.A., Heithaus M.R. (eds.) Biology of sharks and their relatives. 2 edn. CRC Press, Boca Raton, FL, USA.

White W.T., Platell M.E., Potter I.C. 2004. Comparisons between the diets of four abundant species of elasmobranchs in a subtropical embayment: Implications for resource partitioning. Marine Biology 144 (3): 439-448.

WoRMS Editorial Board 2016. World Register of Marine Species. http://www.marinespecies.org (Accessed 2016-07-13).

DOI: $10.14284 / 170$

Yan Y., Chen J., Lu H., Hou G., Lai J. 2012. Feeding habits and ontogenetic diet shifts of hairtail, Trichiurus margarites, in the Beibu Gulf of the South China Sea. Acta Ecologica Sinica 32 (1): 18-25.

DOI: $10.1016 /$ j.chnaes.2011.04.008

Yáñez A.A., Nugent R. 1977. El papel ecológico de los peces en estuarios y lagunas costeras. Anales del Centro Ciencias del Mar y Limnología de la Universidad Nacional Autónoma de México 4 (1): 107-114. DOI: 10.2307/1934593

Zaret T.M., Rand A.S. 1971. Competition in tropical stream fishes: support for the competitive exclusion principle. Ecology 52 (2): 336-342.

Received: 9 March 2016

Accepted: 25 June 2016

Published electronically: 30 June 2016 